Original paper

\title{
Distribution of zooxanthellate zoanthid species (Zoantharia: Anthozoa: Hexacorallia) in southern Japan limited by cold temperatures
}

\author{
James D. REIMER ${ }^{1,2,}$, Shusuke ONO ${ }^{3}$, Frederic SINNIGER ${ }^{1}$, and Junzo TSUKAHARA ${ }^{4}$ \\ ${ }^{1}$ Department of Marine Science, Biology and Chemistry, Faculty of Science, University of the Ryukyus, Senbaru 1, \\ Nishihara, Okinawa 903-0213, Japan. \\ ${ }^{2}$ Research Program for Marine Biology and Ecology, Extremobiosphere Research Center, Japan Agency for Marine- \\ Earth Science and Technology (JAMSTEC), 2-15 Natsushima, Yokosuka, Kanagawa 237-0061, Japan \\ ${ }^{3}$ Miyakonojo Higashi High School, Kabayama 1996, Mimata, Miyazaki 889-1996, Japan \\ ${ }^{4}$ Department of Developmental Biology, Faculty of Science, Kagoshima University, Korimoto 1-21-35, Kagoshima \\ 890-0065, Japan \\ * Corresponding author: J.D. Reimer \\ E-mail: jreimer@sci.u-ryukyu.ac.jp \\ Communicated by Masayuki Hatta (Biology and Ecology Editor)
}

\begin{abstract}
The distribution of several zooxanthellate zoanthid species (Hexacorallia: Anthozoa) from the genera Palythoa, Zoanthus, and Isaurus in the oceans surrounding Japan are generally now well documented, but no examination of potential environmental factors limiting their distribution has been conducted until now. Here, using distribution data from previous works as well as ocean and air temperature data, we examined the minimum ocean temperature threshold for these zoanthid species' existence, as well as what winter air temperatures limit intertidal distribution of zoanthids. Our results show that in the Japan region zooxanthellate zoanthids are limited to oceans with winter temperatures above approximately $16^{\circ} \mathrm{C}$. Additionally, intertidal colonies of zooxanthellate zoanthids were not found in locations where air temperatures dropped below $8^{\circ} \mathrm{C}$. Thus, as with zooxanthellate scleractinian corals, zooxanthellate zoanthid species ranges are strictly limited by minimum ocean (overall range) and air (intertidal distribution) temperatures. Utilizing these threshold data, an examination of the potential
\end{abstract}

ranges of Palythoa, Zoanthus and Isaurus on a global scale shows that it is very likely Atlantic and Indo-Pacific species are isolated from each other, as previously seen with zooxanthellate corals. Additionally, the documented northern Japanese ranges of intertidal occurrences as well as overall distribution northern limits will provide valuable baseline data for future surveys to help ascertain whether tropical and sub-tropical marine species are "invading" northwards in Japan due to global warming.

Keywords Zoanthus, Palythoa, ocean temperature, species range, distribution

\section{Introduction}

The oceans around Japan provide a unique opportunity to examine a wide variety of marine organisms found in waters that range from tropical in the south to temperate in 
the north. In particular, the Nansei (Ryukyu) Islands and Pacific coast until Tokyo Bay are strongly influenced by the warm Kuroshio Current, which carries water northwards from the tropical regions south of Okinawa (see Fig. 1). While the southern Nansei Islands are sub-tropical with year-round ocean temperatures above $20^{\circ} \mathrm{C}$, further north at Shikoku, Wakayama, and the northern Izu Islands there are wide variations in sea temperature from approximately $15^{\circ} \mathrm{C}$ (winter) to $30^{\circ} \mathrm{C}$ (summer). Air temperatures can be even more variable, with temperatures ranging from approximately $0^{\circ} \mathrm{C}$ to $30^{\circ} \mathrm{C}+$ (Table 1 ) for the Pacific coast of mainland Japan. Despite this yearly fluctuation in sea and air temperatures, many corals and other benthic cnidarians are found in surprisingly diverse communities in these areas.

Zooxanthellate zoanthids (Zoantharia) are common benthic colonial cnidarians distributed in shallow tropical and sub-tropical oceans worldwide, and are currently placed in three families; Zoanthidae (including the genera Zoanthus, Isaurus and Acrozoanthus), Sphenopidae (Palythoa) and Parazoanthidae (Parazoanthus with a minority of zooxanthellate species). Similar to hermatypic corals and many other marine invertebrates, zooxanthellate zoanthids are in symbioses with photosynthetic dinoflagellates of the genus Symbiodinium (=zooxanthellae), which provide energy to the host zoanthid (see Trench 1974). It has been shown that Symbiodinium are sensitive to both hot ocean $\left(>30^{\circ} \mathrm{C}\right.$; Iglesias-Prieto et al. 1992) and cold air $\left(<14^{\circ} \mathrm{C}\right.$; Hoegh-Guldberg et al. 2005) and ocean (approx. $12^{\circ} \mathrm{C}$; Hoegh-Guldberg and Fine 2004) temperatures. Unlike their symbionts and despite their cosmopolitan distribution, little is known about the diversity and range of zooxanthellate zoanthid species, especially in sub-tropical areas.

However, the recent use of allozymes (Burnett et al. 1997), and both nuclear and mitochondrial molecular markers has begun to bring order to understanding of zoanthid biodiversity and phylogeny (see Reimer et al. 2004, 2006b, 2006c, 2007a; Sinniger et al. 2005). In particular, the approximate number of species of zooxanthellate zoanthids in Palythoa, Zoanthus and Isaurus; and their ranges in the waters of Japan are now known (see Reimer et al. 2004, 2006b, 2006c, 2007b, 2008b). However, distribution data for zooxanthellate zoanthids in most of the world's subtropical and tropical oceans remain scarce (but see Reimer et al. 2008a,c), making estimating distribution as well as subsequent conservation of zoanthids impossible at the current time.

Here, similar to as was previously successfully shown with zooxanthellate scleractinian corals in Japan (Veron and Minchin 1992), we examine zooxanthellate zoanthid distribution records in Japan, and combined with sea surface temperature data, predict the overall potential distribution of zooxanthellate zoanthids in the northwest Pacific, and minimum ocean temperature thresholds for Zoanthus, Isaurus and Palythoa. We also examine the intertidal distribution of zooxanthellate zoanthids, and compare this with winter air temperature minimums.

\section{Materials and methods}

\section{Zoanthid distribution}

Between 1982 and 2008, the presence and/or distribution of zooxanthellate zoanthids belonging to Zoanthus, Isaurus and Palythoa were checked at numerous sites throughout Japan by snorkeling or SCUBA at depths from intertidal to $30 \mathrm{~m}$ (Fig. 1a). Generally, checks were performed by simply searching for zoanthids in areas where other zooxanthellate hexacorals were found, as zooxanthellate zoanthids are often found in the same environments. Total dive times at all sites investigated ranged from 5 to hundreds of hours. The majority of locations were visited multiple times between 2004 and 2008. Original references for these distributional data include: Reimer (2007), Reimer et al. (2004, 2006a, 2006b, 2006c, 2006d, 2006e, 2007b, 2007d, 2008b) and Ono et al. $(2005,2008)$. If zooxanthellate zoanthids were present, species, and depth range were recorded, and usually voucher specimens and/or in situ images were taken. Additional zoanthid distribution data were kindly supplied by Dr. Hiro'omi Uchida of the Kushimoto Marine Park (Kushimoto, Wakayama), Dr. Yoko Nozawa of the Biological Institute on Kuroshio (Amakusa, Kumamoto), and Dr. Hironobu Fukami of Kyoto University (Shirahama, Wakayama).

\section{Zoanthid species examined}


Eight species of zooxanthellate zoanthids were examined in this study. Three species (Zoanthus sansibaricus Carlgren 1900, Z. gigantus Reimer and Tsukahara 2006, Z. kuroshio Reimer and Ono 2006) belong to the genus Zoanthus, which can be distinguished from most other zoanthid genera by its lack of sand and/or detritus uptake. Although Isaurus spp. (also Family Zoanthidae) similarly do not incorporate detritus into their tissue, unlike Isaurus species' polyps that usually have tubercules Zoanthus polyps are uniformly smooth on the outer surface. One species of Isaurus, I. tuberculatus Gray 1828, was also examined in this study.

Four species of Palythoa (Sphenopidae) were also examined here; P. tuberculosa Delage and Herouard 1901, P. mutuki Carlgren 1937, P. heliodiscus Ryland and Lancaster 2003, and $P$. sp. sakurajimensis sensu Reimer et al. 2007c. Unlike Zoanthidae species, Palythoa species are heavily encrusted with sand, making examination of internal anatomy very difficult.

All zoanthid species listed above are zooxanthellate. However, examinations on the ecology and temperature tolerances of these species are extremely scarce (but see Ono et al. 2002), and little is known about the reproduction of most species except $Z$. sansibaricus (Ono et al. 2005). For detailed descriptions and images of these species, refer to Reimer (2007) and Reimer et al. (2006b).

\section{Ocean temperature data}

Online open access ocean temperature data from the Japan Oceanographic Data Center (JODC) were utilized (www.jodc.go.jp). The "gridded" data show monthly average surface ocean temperatures for one degree latitude by one degree longitude areas for the entire world; in this study we focused on temperatures from the oceans around Japan (see Fig. 1). The ocean temperature for each one degree "squared" area was the product of numerous data ( $n=18 \sim 1545$; global total of 6.84 million pieces of data), collected from many various databases (J-DOSS [18742001], KODC [1961-2002], WOD2001). As demonstrated for zooxanthellate scleractinian corals by Veron and Minchin (1992), we examined whether Japan zooxanthellate zoanthid species' distributions are limited by cold ocean temperatures or not (and therefore also ocean current patterns which influence sea surface temperatures).
Monthly ocean temperature data were seen to be consistently coldest in February, and thus February data were utilized as minimum ocean temperatures. Temperatures were superimposed on the above-mentioned distribution map (Fig. 1). Zoanthid minimum ocean temperature tolerances were estimated by comparing zoanthid species' distributions with minimum ocean temperature data.

\section{Air temperature data}

The data consisted of monthly mean minimum air temperature data from weather stations distributed throughout Japan obtained from open access data of the Japan Meteorological Agency (JMA; www.data.jma.go.jp). The air temperature data for several weather stations nearest zooxanthellate zoanthid sampling locations were utilized (shown in Table 1). Collection periods for the data varied as different stations were built in different years; we used data from 1977-2007 (30 years) to reduce inhomogeneities caused by changes in instrumentation in 1976 at several stations.

By examining monthly mean daily minimum air temperature data (coldest months $=$ January or February) and comparing with presence or absence of zooxanthellate zoanthid species in the intertidal zone, minimum air temperature exposure thresholds for zooxanthellate zoanthids could be estimated as minimum air temperatures occur at night in winter (December-March), the same as large spring tides that expose intertidal organisms. It is possible that a single cold night may limit intertidal distribution, although no records of this exist. On the other hand, it is known zoanthids can survive short-term (i.e. less than a week) exposure to very high $\left(>30^{\circ} \mathrm{C}\right)$ ocean temperatures, and extreme low tide exposure to air and tidepool temperatures of $>37^{\circ} \mathrm{C}$ (Reimer et al. 2007b). Therefore, we have used the monthly mean daily minimum air temperature here for our examinations. Similarly, monthly mean daily maximum air temperature data for summer (July-August) were also obtained.

\section{Analyses}

Distributions of all zooxanthellate zoanthids at various locations (subtidal and/or intertidal) were compared with known winter minimum temperatures and examined for patterns. Additionally, one degree squared areas of Japan 

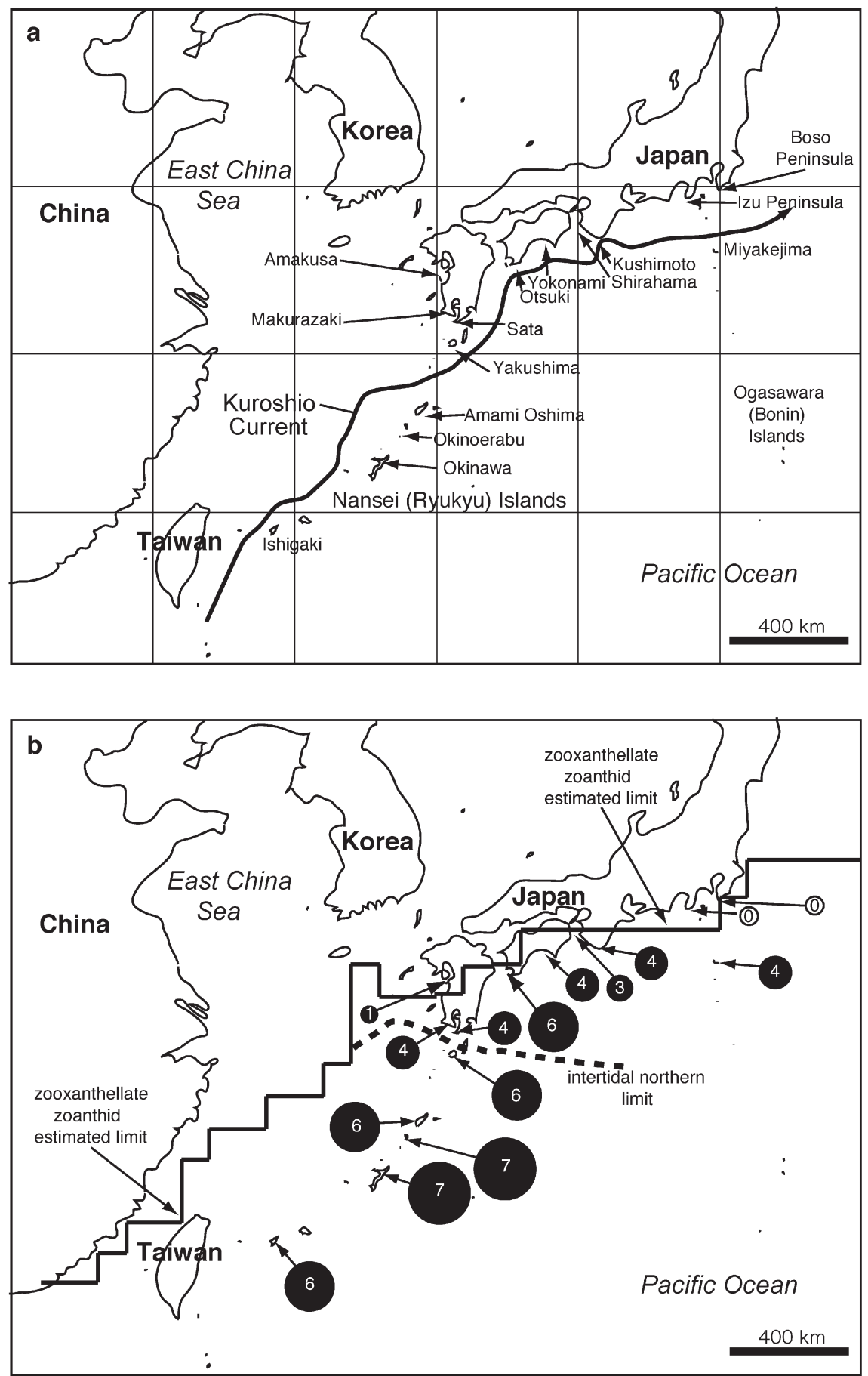

Fig. 1 Map of zooxanthellate zoanthid sampling locations and distribution in Japan and East Asia. a Major sampling locations mentioned in the text and in Table 1. Thick black solid line indicates the approximate path of the warm Kuroshio Current. b Observed and predicted distributions of zooxanthellate zoanthids. Dashed line indicates the winter monthly mean daily minimum air temperature thermocline of $8.0^{\circ} \mathrm{C}$ (JMA data), thus areas south of this line are $>8.0^{\circ} \mathrm{C}$ in winter, and these are the areas for which zooxanthellate zoanthids are predicted to have distribution extending into the intertidal zone. Solid line indicates winter (February) ocean temperature thermocline of $16.0^{\circ} \mathrm{C}$ (JODC data), thus areas south of this line have winter ocean minimum temperatures $>16.0^{\circ} \mathrm{C}$, and zooxanthellate zoanthids are predicted to inhabitat these areas in shallow waters. Black circles with white numbers show the number (also shown by relative circle size) of zooxanthellate zoanthid species found at each location, white circles indicate no zoanthids found at the location. For temperature data details see Materials and methods. 
(excluding Hokkaido) with and without zooxanthellate zoanthids were compared, with average winter minimum temperature calculated for both data sets. Data sets were then compared for significant difference by Fisher's PostHoc PLSD test (StatView 4.0J - Japanese version).

"Coldest" locations for each zoanthid species were also noted to facilitate comparisons between species cold temperature tolerances.

\section{Results and discussion}

\section{Cold ocean temperatures limit zooxanthellate zoanthid distribution}

The results clearly show all zooxanthellate zoanthid species examined in this study limited to ocean areas influenced by the warm Kuroshio Current (Fig. 1b, Table 1). One degree by one degree ocean squares (for winter; February) around Japan with zooxanthellate zoanthids were confirmed to be significantly warmer than squares without zoanthids $\left(19.46 \pm 2.59^{\circ} \mathrm{C}, \mathrm{n}=28\right.$ compared to $11.22 \pm 2.68^{\circ} \mathrm{C}, \mathrm{n}=34$, respectively, $\left.\mathrm{p}<0.001\right)$. As shown in Table 1, there were two critical points in the data. One point was between southern points to Yakushima and all points north, with the northern points not having intertidal distribution of zooxanthellate zoanthids (Table 1, Fig. 1b). The other critical point was between the majority of points, which had zoanthids, and two points without any zooxanthellate zoanthids; Izu and Boso Peninsulas (Table 1, Fig. 1b).

While individual species' thresholds for cold tolerance are apparently slightly different, in general no zooxanthellate zoanthids were found in areas where minimum winter ocean temperatures were below $15.8^{\circ} \mathrm{C}$ (Table 1 , Fig. 1b). Aside from $P$. heliodiscus, which was limited to locations south of Okinoerabu, most species showed the same general distribution along the Pacific coast of Japan, with northern distribution limits in the northern Izu Islands (Miyakejima; Z. sansibaricus, Z. kuroshio Reimer and Ono 2006 in Reimer et al. 2006b, P. mutuki Haddon and Shackleton 1891, P. tuberculosa Klunzinger 1877), Wakayama (Shirahama; Z. gigantus Reimer and Tsukahara 2006 in Reimer et al. 2006b, P. sp. sakurajimensis sensu Reimer et al. 2007c), or Shikoku (Tatsukushi; I. tuber- culatus Gray 1828). P. heliodiscus Ryland and Lancaster 2003 was seen to be least tolerant of cold waters (minimum $=20.85^{\circ} \mathrm{C}$, Okinoerabu), while $Z$. sansibaricus Carlgren 1900 was the most tolerant $\left(15.80^{\circ} \mathrm{C}\right.$, Amakusa) (Table 1).

\section{Intertidal distributions limited by minimum winter air temperatures}

As shown in Fig. 1b and Table 1, many zooxanthellate zoanthids can be found up into the intertidal zone at southern locations but are only subtidal at more northern locations. Minimum ocean temperatures, while limiting overall distribution of zoanthids, are very likely not responsible for this phenomenon, and neither is predation, as no specialized zoanthid predators (e.g. Heliacus spp. sundial snails) unique only to northern Japan are known. Instead, air temperature (maximum or minimum) is likely to be the cause, as seen in algae (Hay 1979) and potentially in coral (Hoegh-Guldberg and Fine 2004).

An examination of summer monthly mean daily maximum air temperatures (JMA data) shows that temperatures between southern Okinawa (e.g. Ishigaki $=31.96^{\circ} \mathrm{C}$ ) and northern mainland Japan (e.g. Shirahama $=32.26^{\circ} \mathrm{C}$ ) are not very different (Table 1). However, minimum winter air temperatures consistently decrease moving northwards (Table 1). Thus, while summer maximum temperatures can also limit distribution of many marine organisms in the intertidal zone through desiccation (e.g. Hay 1979), it appears that cold winter air temperatures limit zooxanthellate zoanthid distribution. Further support for this can be seen in previous documentation of "cold bleaching" in other hexacorallians (Hoegh-Guldberg and Fine 2004).

While occasional zooxanthellate zoanthids were found in tidepools north of Yakushima (e.g. Z. sansibaricus and $Z$. kuroshio at Kashiwajima, P. sp. sakurajimensis at Shirahama), no "exposed" zoanthids outside of tidepools were found intertidally north of Yakushima (winter January mean minimum average temperature $=8.60 \pm$ $1.10^{\circ} \mathrm{C}, \mathrm{n}=30$; 1977-2007). Makurazaki (Fig. 1a, Table 1) has very similar ocean temperatures to Yakushima, but no intertidal zoanthids have been observed here. Interestingly, air temperatures at Makurazaki in winter are $4.64 \pm 1.19^{\circ} \mathrm{C}(\mathrm{n}=30 ; 1977-2007)$, almost $4.0^{\circ} \mathrm{C}$ colder than at Yakushima. Winter air temperatures at Miyakejima 


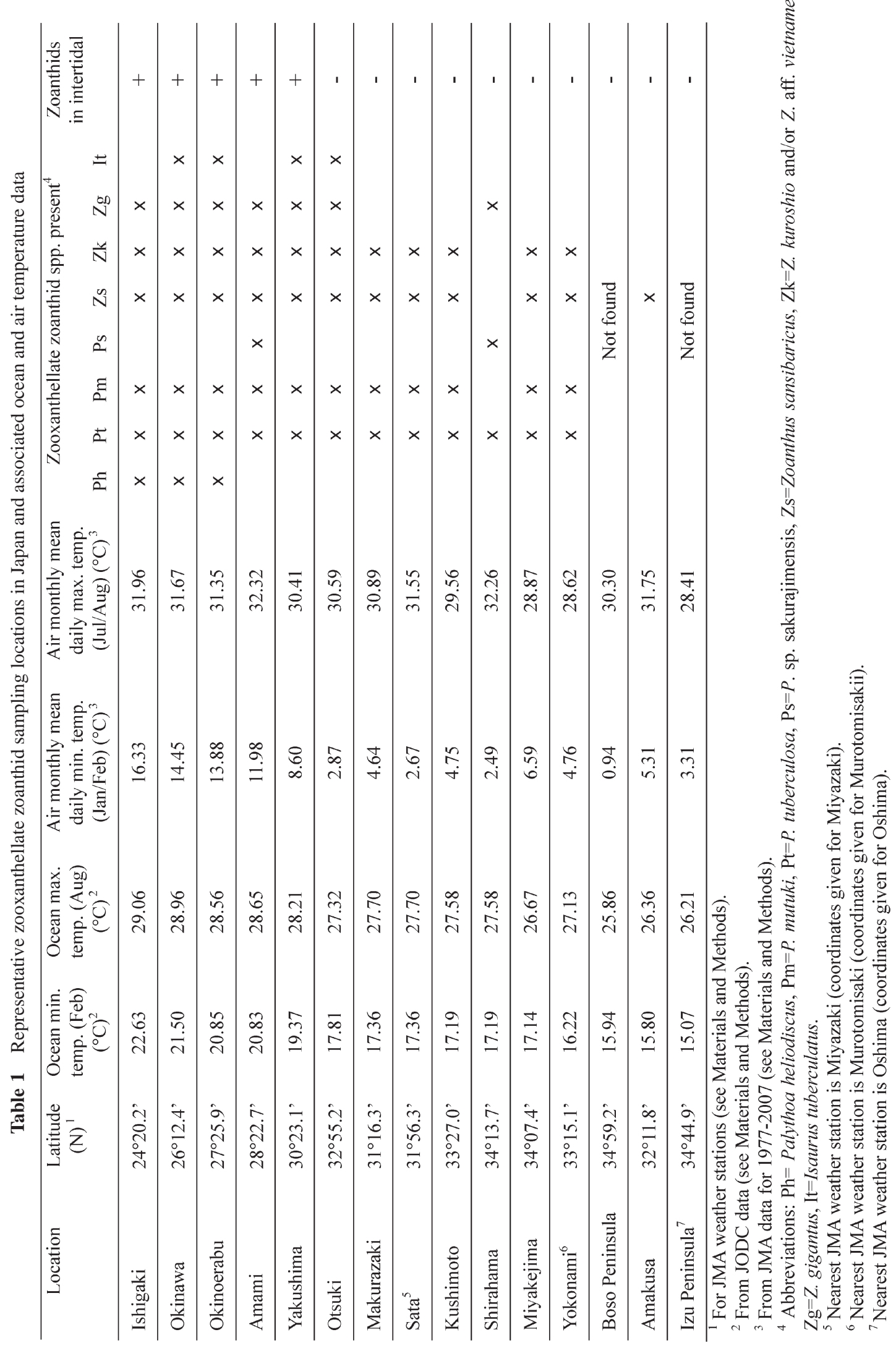


(see Fig. 1a, Table 1) were warmer than Makurazaki but colder than Yakushima $\left(6.59 \pm 1.23^{\circ} \mathrm{C}, \mathrm{n}=29,1977-2007\right.$, February). Thus, for zooxanthellate zoanthids in Japan, here we consider Yakushima and winter minimum mean air temperatures of less than $8.0^{\circ} \mathrm{C}$ to be the effective northern limit for established populations with intertidal distribution of zooxanthellae zoanthid species $Z$. sansibaricus, Z. kuroshio, P. tuberculosa, P. mutuki, and $I$. tuberculatus (Fig. 1b; Table 1).

It would not be entirely unexpected to occasionally find small zooxanthellate zoanthid specimens in "borderline" areas (e.g. southern Izu Peninsula or Boso Peninsula), but it is expected that there are currently no established longterm populations of zooxanthellate zoanthids in these areas based on numerous surveys by the first author, as well as based on winter ocean temperatures in these areas below $15.8^{\circ} \mathrm{C}$. Thus, the predicted intertidal and subtidal zoanthid distributions (Fig. 1b) are for established populations, and not occasional "short-term" colonies that may exist in slightly colder waters.

\section{Predicting zooxanthellate zoanthid distribution ranges}

As shown in Fig. 1a, the influence of the warm Kuroshio Current on water temperatures in the west Pacific is very clear. Waters as far north as the Izu Islands have minimum ocean temperatures $>17.0^{\circ} \mathrm{C}$ (e.g. Miyakejima in Table 1), and thus zooxanthellate zoanthids and some other zooxanthellate hexacorallians are present, while in the western East China Sea ocean temperatures are much colder in winter, and subsequently relatively few zooxanthellate cnidarian species are known from this area (Veron 2000). The solid line in Fig. 1b shows the boundary between oceans $>16^{\circ} \mathrm{C}$ (south) and $<16^{\circ} \mathrm{C}$ (north), and it is expected that zooxanthellate zoanthids are distributed the warmer $>16^{\circ} \mathrm{C}$ water areas. Although data for mainland China are scarce, it is known there are Zoanthus spp. in Hong Kong (J.D. Reimer, surveys in summer 2006; data not shown) and Taiwan (Allen Chen, pers. comm.). Further investigation should help confirm the hypothesized distribution shown in Fig. 1b.

Worldwide, few data on zooxanthellate zoanthids are currently available, although scattered records exist. Examples of potential distribution limits include: Zoanthus danae Le Conte 1852 known from Baja California (Reimer
1971; winter temperature $=16.25^{\circ} \mathrm{C}$ ) and southern Brazil (Boscolo and Silveira 2005; 20.66 ${ }^{\circ} \mathrm{C}$ ); Zoanthus and Palythoa found in South Africa (Carlgren $1938 ; 16.36^{\circ} \mathrm{C}$ ) and in northeastern Florida (C. Foord, pers. comm.; 16.83 ${ }^{\circ} \mathrm{C}$ ), and Isaurus, Zoanthus and Palythoa from western Australia (Carlgren 1954; $18.07^{\circ} \mathrm{C}$ ). Similarly, Palythoa and Zoanthus spp. were seen only at the few locations in the Galapagos where ocean temperatures were yearround consistently greater than $16^{\circ} \mathrm{C}$ (Reimer et al. 2008a; 2008c).

However, asides from zooxanthellate Isozoanthus sulcatus Gosse 1860 of temperate western Europe, no zooxanthellate zoanthid species are known from locations where ocean temperatures reach $<15^{\circ} \mathrm{C} \sim 16^{\circ} \mathrm{C}$. If the prediction here regarding minimum ocean temperatures limiting zooxanthellate zoanthid distribution is applicable globally, then it becomes apparent that Atlantic and IndoPacific populations of Palythoa, Zoanthus and Isaurus are very likely isolated from each other, and likely have been for enough time to diverge into separate sibling species due to cold upwelling off southwest Africa and the closing of the Isthmus of Panama (3.1-3.5 mya; Coates and Obando 1996). This is a similar situation as found in zooxanthellate scleractinian corals, and it has been shown that both many symbiotic Symbiodinium and all host coral species examined thus far are genetically different between the two oceans (LaJeunesse 2005; Fukami et al. 2004, respectively).

While it is likely that Palythoa and Zoanthus spp. from the Atlantic and Pacific are genetically distinct, Muirhead and Ryland (1985) hypothesized that Isaurus tuberculatus is a pan-tropically distributed species. However, I. tuberculatus is not known from cold waters, and is zooxanthellate; therefore the two oceans' populations are very likely separate species. Further support of this comes from Ryland et al. (2000) who show that no potential Sphenopidae larvae have been collected from waters colder than $20^{\circ} \mathrm{C}$, and no Zoanthidae larvae from waters below $18^{\circ} \mathrm{C}$. Additionally, Ono et al. (2002) have noted that $Z$. sansibaricus does not show any growth at all at $16.0^{\circ} \mathrm{C}$. Future research using non-mitochondrial nonconservative molecular markers (as mitochondrial DNA evolves slowly in Anthozoa - see Shearer et al. 2002; Huang et al. 2008) such as the internal transcribed spacer 
region of ribosomal DNA (ITS-rDNA; see Reimer et al. 2007c) may help confirm the separation of Atlantic and Pacific zooxanthellate zoanthids.

\section{Other factors influencing zooxanthellate zoanthid dis- tribution}

One major factor that may strongly limit zooxanthellate zoanthid distribution is the amount of plankton available to benthic cnidarians in a given area. While it is not known how much required energy is gained from the water column for zooxanthellate zoanthids, it may be that for some species this energy is needed on top of energy supplied by Symbiodinium. For example, $P$. tuberculosa colonies are difficult to keep in closed system but well-lit aquaria (FS \& JDR, pers. obs.), and this species has been shown to be a very effective planktonivore (Fabricius and Metzner 2004). Similarly, many zooxanthellate zoanthids are often found in areas with high water flow or exposed to the open ocean, while areas with lower water flow and exposure often have less zoanthids (Reimer 2007). Clearly, detailed research into the energy budgets of zoanthids is needed (but see Trench 1974). Understanding these limitations may allow for predicting distributions to a finer scale than can be done with ocean temperatures alone.

Other potential limiting factors of zooxanthellate zoanthid distribution are dispersal by currents and suitable substrate availability. However, both of these factors are very likely to not be responsible for the distribution patterns observed here. As shown in Fig.1a, both Izu Peninsula and Boso Peninsula are somewhat influenced by the Kuroshio Current similar to many other locations where zoanthids are found (e.g. Yokonami, Kushimoto, etc.), and yet there are no records of any zooxanthellate zoanthids from this region. At the same time, some species of Scleractinia known to be able to withstand slightly colder ocean temperatures have been recorded at these locations (Acropora tumida, Goniopora, Oulastraea; Tsuchiya et al. 2004) as well as in areas where zooxanthellate zoanthids are found. Like zoanthids, hard corals have planula larvae that can drift in currents, and there is no logical explanation why coral larvae would recruit to Izu and Boso Peninsulas and zoanthids would not. Suitable substrate limitation is also unlikely, as the zoanthids in this study have been found on a wide variety of substrates (dead coral, rock, even woody debris) in Japan, which occur in abundance at various locations where no zoanthids have been found.

\section{Future use of northern limits and zoanthid distribu- tion monitoring}

Range expansions due to rapid recent global climate change have been documented for many marine animal species (e.g. Perry et al. 2005), particularly in areas that are becoming warmer. As the oceans around Japan may also experience such warming (Kim et al. 2001), the northern limits of zoanthid species documented here may be pushed further north in the future. The oceans are expected to become more acidic in conjunction with global warming, and this is predicted to strongly negatively impact scleractinian corals (Hoegh-Guldberg et al. 2007). Zoanthids, on the other hand, may not be so impacted by acidification, as they utilize sand and detritus (e.g. Palythoa) or have no encrustation (Zoanthus and Isaurus). These factors combined with relatively fast growth (Karlson 1988) and prolific asexual reproduction (Acosta et al. 2005) may allow zooxanthellate zoanthids to expand their ranges quickly, making them potentially excellent "indicator" species, as seen in some species of fishes (e.g. Parmesan and Yohe 2003). Similarly, a northern extension of intertidal occurrences of zooxanthellate zoanthids may indicate winter air temperatures becoming milder.

Furthermore, it has been observed that $P$. caribaeorum Duchassaing de Fonbressin and Michelotti 1860 in the Caribbean (a potential sibling species to $P$. tuberculosa in the Pacific) are becoming more common in some reef flat areas, suggesting this species may indicate and play a role in a phase shift in community structure at disturbed or degraded reefs (D. Kemp, pers. comm.). Long term monitoring of zoanthid species distribution at a variety of representative reef sites may help reef managers understand and forecast similar phase shifts in the future.

\section{Conclusions}

While the several different zoanthid species here all likely have different physiological requirements, it appears that the majority of species (excepting P. heliodiscus) 
have very similar minimum temperature thresholds. The distributions observed here are further supported by the very similar distributions seen in zooxanthellate scleractinian corals in Japan (Veron and Minchon 1992), limited to areas influenced by the warm Kuroshio Current with minimum water temperatures in winter $>15.8^{\circ} \mathrm{C}$ along the Pacific coast. Further research into some species' zooxanthellae (Z. gigantus, $P$. heliodiscus) as well as investigations on a finer geographic scalemay add further to the theories put forth from this study, but we are confident of the overall general distribution of zooxanthellate zoanthids limited to ocean regions with minimum temperatures $>15.8^{\circ} \mathrm{C}$

It is hoped the results within this study help to formulate predictions for the potential global distribution of zooxanthellate zoanthid species.

\section{Acknowledgements}

C. Foord (Coral Morphologic), Dr. K. Shashank (Kochi University), Dr. H. Fukami (Kyoto University), Dr. Y. Nozawa (Biological Institute on Kuroshio) and Dr. H. Uchida (Kushimoto Marine Center) are thanked for kindly providing additional zooxanthellate zoanthid distribution information. Dustin Kemp (University of Georgia) is thanked for insightful discussions on potential Caribbean phase shifts. The kind comments from both one anonymous reviewer and the editor also improved this manuscript. JDR was supported in part by the $21^{\text {st }}$ Century Center of Excellence (COE) program at the University of the Ryukyus. FS was supported by a Japan Society for the Promotion of Science (JSPS) post-doctoral fellowship.

\section{References}

Acosta A, Sammarco PW, Duarte LF (2005) New fission processes in the zoanthid Palythoa caribaeorum: description and quantitative aspects. Bull Mar Sci 76: 1-26

Boscolo HK, Silveira FL (2005) Reproductive biology of Palythoa caribaeorum and Protopalythoa variabilis (Cnidaria, Anthozoa, Zoanthidea) from the southeastern coast of Brazil. Braz J Biol 65: 29-41
Burnett WJ, Benzie JAH, Beardmore JA, Ryland JS (1997) Zoanthids (Anthozoa, Hexacorallia) from the Great Barrier Reef and Torres Strait, Australia: systematics, evolution and a key to species. Coral Reefs 16: 55-68

Carlgren O (1938) South African Actiniaria and Zoantharia. K Svenska Vetenskaps-Akad Handl 17: 1-148

Carlgren O (1954) Actiniaria and Zoantharia from South and West Australia with comments upon some Actiniaria from New Zealand. Ark Zool 6: 571-595

Coates AG, Obando JA (1996) The geological evolution of the Central American isthmus. In: Jackson JBC, Budd AF, Coates AG (eds) Evolution and environment in tropical America. University of Chicago Press, Chicago, pp 21-56

Fabricius KE, Metzner J (2004) Scleractinian walls of mouths: predation on coral larvae by corals. Coral Reefs 23: 245248

Fukami H, Budd AF, Paulay G, Sole-Cava A, Chen AC, Iwao K, Knowlton N (2004) Conventional taxonomy obscures deep divergence between Pacific and Atlantic corals. Nature 427: 832-835

Hay C (1979) Some factors affecting the upper limit of the southern bull kelp Durvillaea antarctica (Chamisso) Hariot on two New Zealand shores. J Roy Soc NZ 9: 279-289

Hoegh-Guldberg O, Fine M (2004) Low temperatures cause coral bleaching. Coral Reefs 23: 444

Hoegh-Guldberg O, Fine M, Skirving W, Johnstone R, Dove S, Strong A (2005) Coral bleaching following wintry weather. Limnol Oceanogr 501: 265-271

Hoegh-Guldberg O, Mumby PJ, Hooten AJ, Steneck RS, Greenfield P, Gomez E, Harvell CD, Sale PF, Edwards AJ, Caldeira K, Knowlton N, Eakin CM, Iglesias-Prieto R, Muthiga N, Bradbury RH, Dubi A, Hatziolos ME (2007) Coral reefs under rapid climate change and ocean acidification. Science 318: 1737-1742

Huang D, Meier R, Todd PA, Chou LM (2008) Slow mitochondrial COI sequence evolution at the base of the metazoan tree and its implications for DNA barcoding. J Mol Evol [DOI 10.1007/s00239-008-9069-5] (in press)

Iglesias-Prieto R, Matta JL, Robins WA, Trench RK (1992) Photosynthetic response to elevated temperature in the symbiotic dinoflagellate Symbiodinium microadriaticum in culture. Proc Natl Acad Sci USA 89: 10302-10305

Karlson RH (1988) Growth and survivorship of clonal fragments in Zoanthus solanderi Lesueur. J Exp Mar Biol Ecol 123: 31-39

Kim K, Kim KR, Min DH, Volkov Y, Yoon JH, Takematsu M (2001) Warming and structural changes in the East (Japan) 
Sea: a clue to future changes in global oceans? Geophy Res Lett 28: 3293-3296

LaJeunesse TC (2005) "Species" radiations of symbiotic dinoflagellates in the Atlantic and Indo-Pacific since the Miocene-Pliocene transition. Mol Biol Evol 22: 570-581

Muirhead A, Ryland JS (1985) A review of the genus Isaurus Gray 1828 (Zoanthidea), including new records from Fiji. J Natural History 19: 323-335

Ono S, Reimer JD, Tsukahara J (2002) Seasonal changes in Zoanthus spp. in the infra-littoral zone at Taisho Lava Field, Sakurajima, Kagoshima, Japan. South Pacific Study 22: 41-52.

Ono S, Reimer JD, Tsukahara J (2005) Reproduction of Zoanthus sansibaricus in the infra-littoral zone at Taisho Lava Field, Sakurajima, Kagoshima, Japan. Zool Sci 22: 247-255

Ono S, Reimer JD, Tsukahara J (2008) Survey of zooxanthellate zoanthid diversity in Kagoshima, Japan. Kuroshio Biosphere 4: 1-16

Parmesan C, Yohe G (2003) A globally coherent fingerprint of climate change impacts across natural systems. Nature 421: $37-42$

Perry AL, Low PJ, Ellis JR, Reynolds JD (2005) Climate change and distribution shifts in marine fishes. Science 308: 19121915

Reimer AA (1971) Observations of the relationships between several species of tropical zoanthids (Zoanthidea, Coelenterata) and their zooxanthellae. J Exp Mar Biol Ecol 7: 207-214

Reimer JD (2007) Preliminary survey of zooxanthellate zoanthid diversity (Hexacorallia: Zoantharia) from southern Shikoku, Japan. Kuroshio Biosphere 3: 1-16+7 pls.

Reimer JD, Ono S, Takishita K, Fujiwara Y, Tsukahara J (2004) Reconsidering Zoanthus spp. diversity: molecular evidence of conspecifity within four previously presumed species. Zool Sci 21: 517-525

Reimer JD, Ono S, Iwama A, Tsukahara J, Maruyama T (2006a) High levels of morphological variation despite close genetic relatedness between Zoanthus aff. vietnamensis and Zoanthus kuroshio (Anthozoa: Hexacorallia). Zool Sci 23: 755-761

Reimer JD, Ono S, Iwama A, Tsukahara J, Takishita K, Maruyama $\mathrm{T}$ (2006b) Morphological and molecular revision of Zoanthus (Anthozoa: Hexacorallia) from southwestern Japan with description of two new species. Zool Sci 23: 261-275

Reimer JD, Ono S, Takishita K, Tsukahara J, Maruyama T (2006c) Molecular evidence suggesting species in the zoanthid genera Palythoa and Protopalythoa (Anthozoa: Hexacorallia) are congeneric. Zool Sci 23: 87-94

Reimer JD, Takishita K, Maruyama T (2006d) Molecular identification of symbiotic dinoflagellates (Symbiodinium spp.) from Palythoa spp. (Anthozoa: Hexacorallia) in Japan. Coral Reefs 25: 521-527

Reimer JD, Takishita K, Ono S, Maruyama T, Tsukahara J (2006e) Latitudinal and intracolony ITS-rDNA sequence variation in the symbiotic dinoflagellate genus Symbiodinium (Dinophyceae) in Zoanthus sansibaricus (Anthozoa: Hexacorallia). Phycol Res 54: 122-132

Reimer JD, Hirano S, Fujiwara Y, Sinniger F, Maruyama T (2007a) Morphological and molecular characterization of Abyssoanthus nankaiensis, a new family, new genus and new species of deep-sea zoanthid (Anthozoa: Hexacorallia: Zoantharia) from a northwest Pacific methane cold seep. Invert Systematics 21: 255-262

Reimer JD, Ono S, Furushima Y, Tsukahara J (2007b) Seasonal changes in the morphological condition of symbiotic dinoflagellates (Symbiodinium spp.) of Zoanthus sansibaricus (Anthozoa: Hexacorallia) over a latitudinal range in southern Japan. South Pacific Study 27: 1-24

Reimer JD, Takishita K, Ono S, Maruyama T (2007c) Diversity and evolution in the zoanthid genus Palythoa (Cnidaria: Hexacorallia) utilizing nuclear ITS-rDNA. Coral Reefs 26: 399-410

Reimer JD, Takishita K, Ono S, Tsukahara J, Maruyama T (2007d) Molecular evidence suggesting intraspecific hybridization in Zoanthus (Anthozoa: Hexacorallia). Zool Sci 24: 346-359

Reimer JD, Hickman CPH (2008a) Preliminary survey of zooxanthellate zoanthids (Cnidaria: Hexacorallia) of the Galápagos and associated symbiotic dinoflagellates (Symbiodinium spp.). Galapagos Res (in press)

Reimer JD, Ono S, Tsukahara J, Iwase F (2008b) Molecular characterization of the zoanthid genus Isaurus (Anthozoa: Hexacorallia) and associated zooxanthellae (Symbiodinium spp) from Japan. Mar Biol 153: 351-363

Reimer JD, Sinniger F, Hickman CP Jr (2008c) Zoanthid diversity (Anthozoa: Hexacorallia) in the Galapagos Islands: a molecular examination. Coral Reefs 27: 641-654

Ryland JS, de Putron S, Scheltema RS, Chimonides PJ, Zhadan DG (2000) Semper's (zoanthid) larvae: pelagic life, parentage and other problems. Hydrobiologia 440: 191198

Shearer TL, van Oppen MJH, Romano SL, Worheide G (2002) Slow mitochondrial DNA sequence evolution in the 
Anthozoa (Cnidaria). Mol Ecol 11:2475-2487

Sinniger F, Montoya-Burgess JI, Chevaldonne P, Pawlowski J (2005) Phylogeny of the order Zoantharia (Anthozoa: Hexacorallia) based on mitochondrial ribosomal genes. Mar Biol 147: 1121-1128

Trench RK (1974) Nutritional potentials in Zoanthus sociatus (Coelenterata, Anthozoa). Helgolander wiss. Meersunters 26: $174-216$

Tsuchiya M, Nadaoka K, Kayanne H, Yamano H (eds) (2004) Coral reefs of Japan. Ministry of the Environment, Tokyo.
Veron JEN (2000) Corals of the World. Australian Institute of Marine Science; Townsville, Australia. 3 vols.

Veron JEN, Minchin PR (1992) Correlations between sea surface temperature, circulation patterns and the distribution of hermatypic corals in Japan. Cont Shelf Res 12: 835-857

Received: 25 July 2008 Accepted: 12 November 2008

(C) Japanese Coral Reef Society 